\title{
Conjugation Systems of IncT Plasmids
}

\author{
By DAVID E. BRADLEY* AND JEANETTE WHELAN \\ Faculty of Medicine, Memorial University of Newfoundland, St. John's, Newfoundland, \\ Canada $A 1 B 3 V 6$
}

(Received 21 February 1985; revised 3 June 1985)

Four IncT plasmids were compared for various characters, in particular pilus synthesis and
function at different temperatures. The prototype Rts l differed in some respects from the others
(R402, R 394 , pIN25). At $37^{\circ} \mathrm{C}$, the supposedly temperature-sensitive conjugation systems of the
plasmids could still function efficiently on a surface, but not in a liquid. Long conjugative pili
were synthesized at $30^{\circ} \mathrm{C}$, but only short ones (approx. $200 \mathrm{~nm}$ ) were produced at $37^{\circ} \mathrm{C}$. The
long pili converted two surface-obligatory conjugation systems to surface + liquid ones at $30^{\circ} \mathrm{C}$.

\section{INTRODUCTION}

The prototype IncT plasmid Rtsl (Terawaki et al. 1967; Terawaki \& Rownd, 1972) has temperature-sensitive replication and transfer systems. Other members of this incompatibility group (R394, R401, R402) have been described by Coetzee et al. (1972), with more being added recently (Matthew \& Hedges, 1976; Odakura et al., 1977; Levy et al., 1985). R394 alone is not temperature-sensitive (Coetzee et al., 1972).

Although $\mathrm{t}$ is the prototype IncT plasmid, Rtsl appears to be significantly different from the others. (For a more detailed description of IncT plasmids, see Bradley et al., 1981.) Because of their temperature-sensitivity, the repressed nature of Rtsl, and the availability of a pilusspecific phage (Bradley et al., 1981), the IncT plasmids were chosen for investigating some aspects of the function of thick flexible pili in conjugation. The temperature-sensitivities of four IncT plasmid transfer systems were compared to find out if they were due to failure of pilus function or synthesis at elevated temperatures.

\section{METHODS}

Bacteria, plasmids and bacteriophages. The host organism for plasmids was Escherichia coli strain JE2571 (leu thr strfla pil), together with its nalidixic acid- and rifampicin-resistant derivatives (suffices -1 and -2 respectively). Salmonella typhimurium LT2 strain SQ1139 (purC proA il strflapil) was also used in one experiment. Plasmids and resistances determined were: R402 (ampicillin, carbenicillin, streptomycin), Rts (kanamycin), R394 (ampicillin, carbenicillin, kanamycin), pIN25 (ampicillin, carbenicillin, kanamycin). All save pIN25 were supplied by Dr N. Datta (Datta, 1977; Jacob et al., 1977). pIN25 was supplied by Dr S. B. Levy (Levy et al. 1985). The IncHIl plasmid R27: :Tn7, a derepressed mutant of R27, was supplied by Dr D. E. Taylor (Taylor, 1983). The T pilus-specific RNA bacteriophage t was described by Bradley et al. (1981).

Media, matings and hacteriophage techniques. These, including drug concentrations, were as described by Bradley (1984) and Bradley et al. (1981). For comparative plate and broth matings, an overnight static broth culture, incubated at the optimum transfer temperature of the test plasmid ( RP4 and Sa, $37^{\circ} \mathrm{C}$; IncT plasmids, $30^{\circ} \mathrm{C}$ ), was used to inoculate a shake culture, which was grown at $\mathrm{l}-2 \times 10^{9}$ bacteria $\mathrm{ml}^{-1}$ at the mating temperature. A sample $(2.5 \mathrm{ml})$ of this was mixed with a similar amount of an identical culture of recipient strain JE2571-1 (grown overnight at $37 \mathrm{C}$ in all cases). The mating mixture was then used for the comparative matings at the test temperature (Bradley et al., 1980). The stability of a plasmid's derepressed character (Bradley, 1984) was assayed by testing 50 colonies from viable counts on non-selective plates for sensitivity to phage t.

Agarose gel electrophoresis. Plasmid DNA, prepared as described by Kado \& Liu (1981), was run on a horizontal gel electrophoresis system (Bethesda Research Laboratories) with the manufacturer`s agarose at $0.7 \%(w / v)$ concentration. A series of plasmid DNA standards was used for calibration. 
Electron microscopy. Immune electron microscopy using antiserum to T pili was described by Bradley (1980). The average number of pili per cell for strain JE2571 carrying the IncT plasmids under study was assessed at various temperatures. Overnight static broth cultures at $30^{\circ} \mathrm{C}$ were used to inoculate a culture shaken at the test temperature. At $\mathrm{OD}_{620}=1.0$ (about $3 \mathrm{~h}$ ), the shaker was turned off and incubation continued statically for $15 \mathrm{~min}$ to allow pilus outgrowth. A carbon-coated support grid was floated on the surface of the culture for $1 \mathrm{~min}$, then floated on $0.1 \mathrm{M}$-ammonium acetate solution, and negatively stained with $0.2 \%$ ( $/ / v$ ) sodium phosphotungstate solution (Bradley, 1980). These operations were done at the test temperature in a short time (1-2 min) to prevent possible additional pilus outgrowth on the grid. The pili on 50 random cells were then counted in the electron microscope; the pili per cell and the percentage of piliated cells were calculated.

Pili were mounted directly from non-selective plate cultures grown overnight at various temperatures as follows. A carbon-coated specimen support grid was gently pressed, carbon downwards, onto the surface of the thinnest bacterial growth not separated into discrete colonies. It was then washed and negatively stained as described by Bradley (1980).

For the adsorption of phage t to short $\mathrm{T}$ pili, a pilus suspension was prepared as described previously (Bradley, 1980) from strain JE2571 (pIN25) grown overnight on non-selective plates at $41^{\circ} \mathrm{C}$, with all subsequent processing being done at $37^{\circ} \mathrm{C}$ in a hot room. The pilus suspension was mixed with a high titre pilus-free phage suspension and incubated for $30 \mathrm{~min}$ at $37^{\circ} \mathrm{C}$. A carbon-coated support grid was touched on the surface and negatively stained as above.

\section{RESULTS}

\section{Characteristics of IncT plasmids}

pIN25 was the only one of the four IncT plasmids not previously tested for the temperaturesensitivity of its replication system. The replication of R402 is temperature-sensitive, whereas that of R394 is not (Coetzee et al., 1972). Terawaki et al. (1967) demonstrated the temperaturesensitivity of Rts 1 replication. Using their method, JE2571(pIN25) gave 50/50 colonies retaining its kanamycin resistance marker after growth in non-selective static culture for $24 \mathrm{~h}$ at $37^{\circ} \mathrm{C}$, compared with $46 / 50$ for the R 402 carbenicillin-resistance marker. For the same markers at $43{ }^{\circ} \mathrm{C}$, the result for JE2571(pIN25) was 13/50, and for JE2571-2(R402), 4/50. While temperature-sensitive, the replication of pIN25 is thus somewhat less so than that of R402.

The four IncT plasmids were tested both for their ability to specify sensitivity to phage $t$, and for the stability of transfer-derepression at $30^{\circ} \mathrm{C}$ and $37^{\circ} \mathrm{C}$. It was confirmed that strains carrying R402, R394 and pIN25 were lysed by the phage at $30^{\circ} \mathrm{C}$ (Bradley et al., 1981), indicating constitutive synthesis of T pilus receptors. Strain JE2571(Rts1) gave hazy clearing, unlike strain J53(Rts1) which gave none (Bradley et al., 1981; Bradley \& Fleming, 1983). The JE2571(Rtsl) response was not some form of growth inhibition or bacteriocin-like action since very hazy individual plaques were visible with dilute phage preparations (see Bradley, 1967). At $37^{\circ} \mathrm{C}$, none of the strains carrying the plasmids was visibly lysed, suggesting possible loss of the derepressed character. The stability of the derepressed character was therefore assessed by growing strains harbouring the three derepressed plasmids (R402, R394, pIN25) in drug-free media at $37^{\circ} \mathrm{C}$, and then testing colonies for phage t lysis at $30^{\circ} \mathrm{C}$ (see Methods). For all three, the original sensitivity to phage $\mathrm{t}$ was restored for all colonies indicating $100 \%$ stability of the derepressed character.

Plasmid molecular weights were R402 $=86 \times 10^{6}, \mathrm{R} 394=90 \times 10^{6}$ and pIN25 $=86 \times$ $10^{6}$. Rtsl has been reported as larger, at $140 \times 10^{6}$ (Ishihara et al., 1978). It was also supposed to specify resistance to copper (Ishihara et al., 1978), but Tetaz \& Luke (1983) were unable to confirm this. We tested all four plasmids using the medium of Tetaz \& Luke (1983) and found no copper resistance.

\section{Effect of temperature on the optimum mating environment of IncT plasmids}

Some plasmids transfer better on plates than in broth (surface-obligatory conjugation systems), and others are equally good in both environments (surface + liquid or universal systems). IncT plasmids are of the latter kind (Bradley et al., 1980) at $30^{\circ} \mathrm{C}$, but comparisons of transfer frequencies for broth and plate matings have not been done for higher temperatures. We found unexpectedly that at $37^{\circ} \mathrm{C}$ the universal systems of all four plasmids tested were converted to the surface-obligatory type (Table 1). R402 and Rts1 both transferred at lower 
Table 1. Effect of temperature on conjugation systems

The plasmid host strain was JE2571-2, and the recipient JE2571-1, nalidixic acid (20 $\left.\mu \mathrm{g} \mathrm{ml}^{-1}\right)$ being the counterselecting drug. For $37^{\circ} \mathrm{C}$ matings the overnight static cultures used to inoculate shake cultures were grown at $30^{\circ} \mathrm{C}$, all other cultures being grown at $37^{\circ} \mathrm{C}$ (see Methods).

\begin{tabular}{|c|c|c|c|c|c|c|c|}
\hline \multirow[b]{3}{*}{ Plasmid } & \multirow[b]{3}{*}{ Selection* } & \multicolumn{6}{|c|}{ Transfer frequenciest and plate broth ratios $_{+}^{+}$} \\
\hline & & \multicolumn{3}{|c|}{$30^{\circ} \mathrm{C}$} & \multicolumn{3}{|c|}{$37^{\circ} \mathrm{C}$} \\
\hline & & Plate & Broth & Ratio & Plate & Broth & Ratio \\
\hline R402 & $\mathrm{Cb}$ & $1.3 \times 10^{\circ}$ & $1.6 \times 10^{-1}$ & 8 & $8.6 \times 10^{-2}$ & $1 \cdot 1 \times 10^{-5}$ & 7800 \\
\hline R394 & $\mathrm{Km}$ & $1.0 \times 10^{0}$ & $1.6 \times 10^{-1}$ & 6 & $7.3 \times 10^{-1}$ & $4.6 \times 10^{-+}$ & 1600 \\
\hline pIN25 & $\mathrm{Km}$ & $1.2 \times 10^{0}$ & $1.8 \times 10^{-1}$ & 7 & $5.5 \times 10^{-1}$ & $3.2 \times 10^{-4}$ & 1700 \\
\hline Rtsl & $\mathrm{Km}$ & $7.3 \times 10^{-2}$ & $2.7 \times 10^{-3.3}$ & 27 & $6.0 \times 10^{-4}$ & $1.8 \times 10^{-7}$ & 3300 \\
\hline
\end{tabular}

frequencies on plates at $37^{\circ} \mathrm{C}$ compared with $30^{\circ} \mathrm{C}$, but the differences were much larger for broth matings, accounting for high plate/broth transfer frequency ratios (the higher the ratio, the more surface-dependent the system). The frequency ratios for R394 and pIN25 were lower, but their conjugation systems were also surface-obligatory. RP1 has a surface mating system [ratio 2100 (Bradley, et al., 1980) compared with approx. 1600 for R394] but RP1 determined rigid pili, not flexible ones giving universal mating systems as with IncT plasmids. The plate mating frequencies for R394 and pIN25 at $37^{\circ} \mathrm{C}$ were almost as high as at $30{ }^{\circ} \mathrm{C}$ but the broth mating frequencies were very much lower (Table 1). It seemed possible that this conversion of mating types might extend to other plasmids exhibiting temperature-sensitivity. Therefore, a plasmid of the $\mathrm{H}$ complex ( $\mathrm{R} 27:: \operatorname{Tn} 7)$ was similarly tested, but its conjugation system was not changed to surface-obligatory, there being no detectable transfer in broth or on plates at $37^{\circ} \mathrm{C}$ (see also Taylor \& Levine, 1980).

\section{Effect of temperature on the pili determined by IncT plasmids}

IncT plasmids Rts1, R402 and R394 all determine serologically related thick flexible conjugative pili at $30^{\circ} \mathrm{C}$ (Bradley, 1980). Immune electron microscopy revealed a strong reaction between the constitutively-determined pIN25 pili and antiserum to R402 pili (not illustrated) showing that pIN25 pili were of the T serotype. Fig. 1 shows the effect of temperature on the piliation of strain JE2571 carrying R402, R394 or pIN25. Rts1 is not included since it determined no pili for a 100 cell sample at $30^{\circ} \mathrm{C}$ under the conditions of the estimation (see Methods). The starting temperature of $30^{\circ} \mathrm{C}$ was chosen because a test with R402 showed that piliation fell at $29^{\circ} \mathrm{C}$ to the same value as at $31^{\circ} \mathrm{C}$ and pilus counts had to be limited to a manageable number. The number of pili per cell (Fig. 1 a) dropped progressively for all three plasmids from between 5 and 10 pili per cell at $30^{\circ} \mathrm{C}$ to between 0 and 0.1 pili per cell at $37^{\circ} \mathrm{C}$. However, the percentage of cells piliated (Fig. $1 \mathrm{~b}$ ) remained more or less constant before falling sharply at $32^{\circ} \mathrm{C}$ for $\mathrm{R} 402,33^{\circ} \mathrm{C}$ for R 394 and $34^{\circ} \mathrm{C}$ for pIN25.

In spite of the fact that there were virtually no pili on cells at $37^{\circ} \mathrm{C}$, all the plasmids transferred efficiently on plates (see above). It seemed very likely that some sort of pilus would be required for such transfer, and that short or rigid ones were the most probable. However, there were no pili on cells of strain JE2571(pIN25) when they were grown under the same conditions as described for Fig. 1 (see Methods) using light negative staining so that the cell surface was clearly visible. Because of the possibility that short pili might be obscured by wrinkling of the bacterial envelope, we sought detached pili by mounting bacteria directly from plates grown at various temperatures. At permissive temperatures for piliation (below $32^{\circ} \mathrm{C}$, see Fig. 1) JE2571(pIN25) synthesized many long pili and a number of short ones (Fig. $2 a$, prepared at $31{ }^{\circ} \mathrm{C}$ ). At $37^{\circ} \mathrm{C}$ and above, the long ones disappeared leaving only short pili about $200 \mathrm{~nm}$ in 


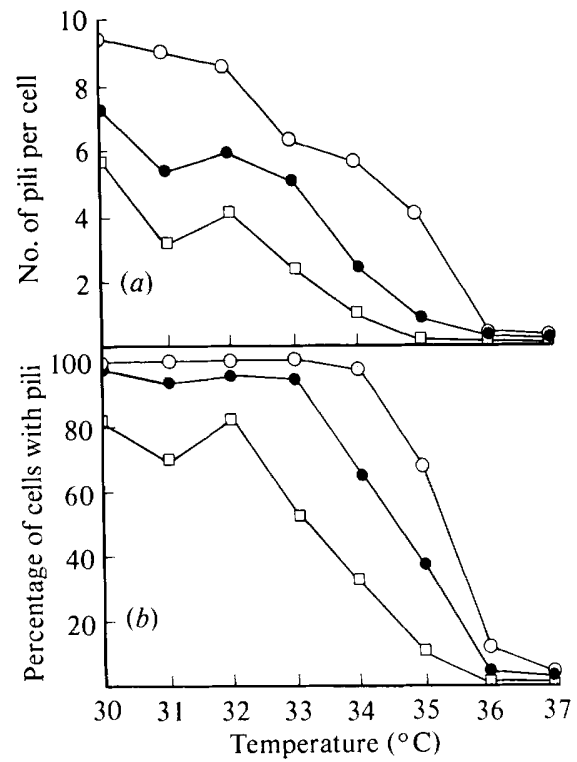

Fig. 1. Piliation of strains carrying the three transfer-derepressed IncT plasmids: O, pIN25;, R394; $\square$, R402. Average number of pili per cell $(a)$, and percentage of cells with pili $(b)$ determined from samples of 50 cells (see Methods).
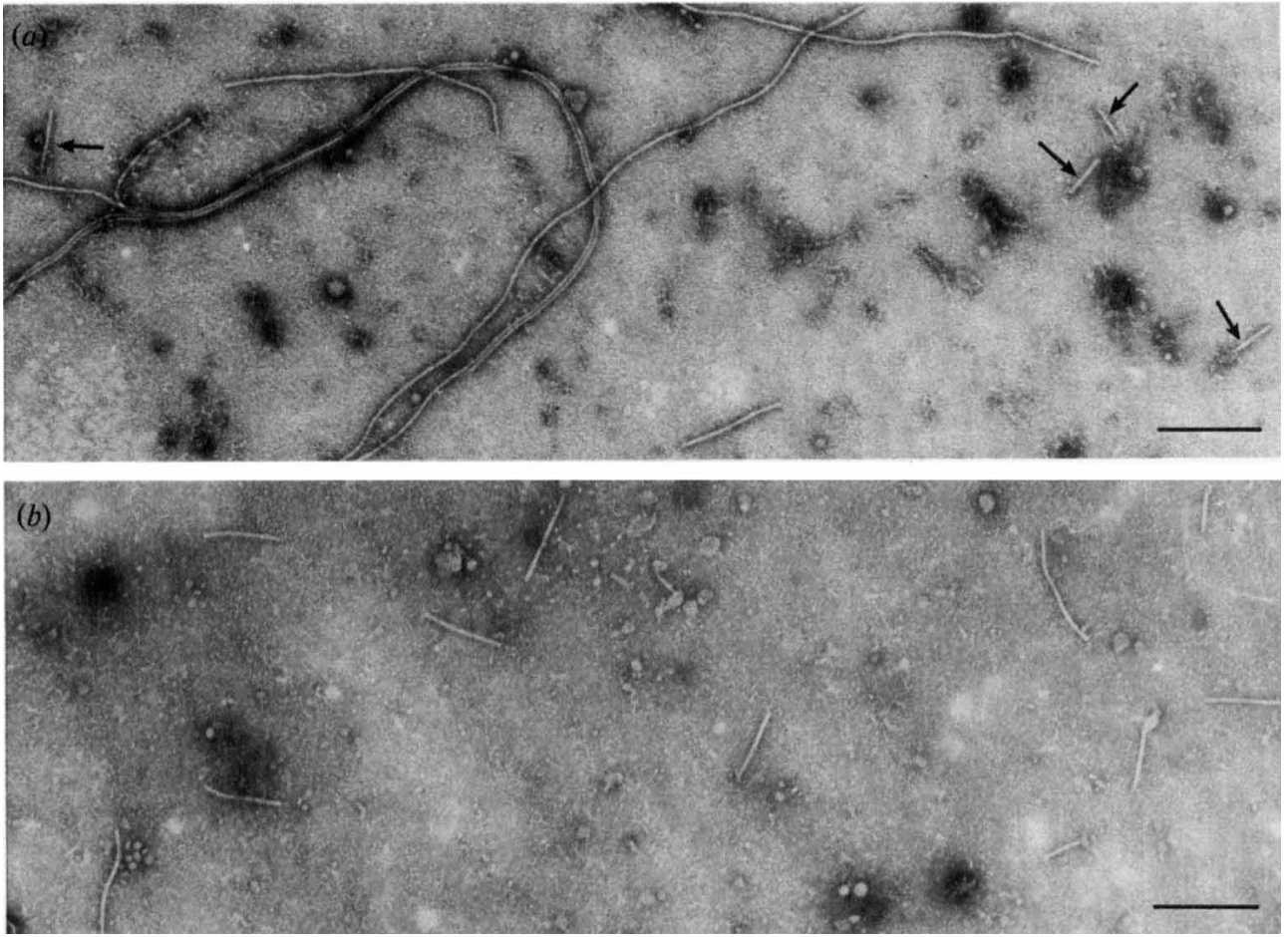

Fig. 2. Pili synthesized by strain JE2571(pIN25) at $31^{\circ} \mathrm{C}(a)$ and $41^{\circ} \mathrm{C}(b)$. Arrows indicate short pili in (a). Bar markers represent $250 \mathrm{~nm}$. 
Table 2. Effect of $T$ pili on the surface mating characteristics of plasmids RP4 and Sa

\begin{tabular}{|c|c|c|c|c|c|c|c|}
\hline \multirow[b]{2}{*}{ Donor } & \multirow[b]{2}{*}{ Recipient } & \multirow[b]{2}{*}{ Selection* } & \multirow[b]{2}{*}{$\begin{array}{c}\text { Temp. } \\
\text { ('C) }\end{array}$} & \multicolumn{2}{|c|}{ Transfer frequencies $\dagger$} & \multirow[b]{2}{*}{$\begin{array}{c}\text { Plate broth } \\
\text { ratio }\end{array}$} & \multirow{2}{*}{$\begin{array}{l}\text { Improvement } \\
\text { in ratio by } \\
\text { recipient } \\
\text { plasmids } \$\end{array}$} \\
\hline & & & & Plate & Broth & & \\
\hline JE2571-2(RP4) & JE257!-1 & $\mathrm{Tc}$ & 30 & $1.2 \times 10^{\circ}$ & $7.5 \times 10^{-6}$ & 160000 & -. \\
\hline JE2571-2(RP4) & JE2571-1(pIN25) & Tc & 30 & $2.5 \times 10^{-1}$ & $2.4 \times 10^{-3}$ & 100 & 1500 \\
\hline JE2571-2(RP4) & JE2571-1(Rts1) & $\mathrm{Tc}$ & 30 & $2.5 \times 10^{-1}$ & $2.7 \times 10^{-5}$ & 9300 & 17 \\
\hline JE2571-2(Sa) & JE2571-1 & $\mathrm{Cm}$ & 30 & $1.1 \times 10^{0}$ & $1.2 \times 10^{-5}$ & 92000 & - \\
\hline JE2571-2(Sa) & JE2571-L(R402) & $\mathrm{Cm}$ & 30 & $5.6 \times 10^{-1}$ & $3.2 \times 10^{-2}$ & 18 & 5000 \\
\hline JE2571-2(Sa) & JE2571-1(Rts1) & $\mathrm{Cm}$ & 30 & $1.2 \times 10^{0}$ & $2.0 \times 10^{-4}$ & 6000 & 15 \\
\hline JE2571-2(Sa) & JE2571-1 & $\mathrm{Cm}$ & 37 & $1.2 \times 10^{\circ}$ & $5.0 \times 10^{-5}$ & 27000 & - \\
\hline JE2571-2(Sa) & JE2571-1(R402) & $\mathrm{Cm}$ & 37 & $2.3 \times 10^{\circ}$ & $1.6 \times 10^{-3}$ & 1400 & 19 \\
\hline
\end{tabular}

length (Fig. $2 b$, prepared at $41^{\circ} \mathrm{C}$ ). R402 and R394 were similar. To determine whether these short pili were a second type of pilus completely different from the long ones, or whether they were merely short versions of the long ones, we adsorbed a pilus-free suspension of phage $t$ to them. This highly specific RNA phage, which adsorbs to the shafts of $T$ pili. attached just as well to short pili at its adsorption site near the tips as it did to long pili (observation not illustrated; see Bradley et al., 1981). It was also noted that the short pili gave a strong reaction with antiserum against R402 pili (normal long pili) by immune electron microscopy. There was thus no doubt that the short pili were the same as the long pili.

Conjugation systems of RP4 (IncP) and Sa (IncW) in the presence and absence of T pili

Thin I pili stabilize mating aggregates allowing surface-obligatory conjugation systems to function in a liquid (Bradley, 1984). They do this equally well when present on recipient or donor cells. T pili were tested to assess their ability to convert surface systems to surface + liquid ones. Transfer frequencies on plates and in broth were compared for matings with and without IncT plasmids in the recipient only (so avoiding mobilization, etc., of the second plasmid) for two surface-mating plasmids at $30^{\circ} \mathrm{C}$ (optimum temperature $\mathrm{T}$ pilus synthesis: see above). The effects of pIN25 on the RP4 conjugation system, and R402 on the Sa system were pronounced (Table 2). Plate/broth transfer frequency ratios were reduced about $150(0$-fold and 5000 -fold respectively. The transfer frequency ratios of RP4 and Sa on their own were much higher at $30^{\circ} \mathrm{C}$ than at $37^{\circ} \mathrm{C}$ (see Table 2 and Bradley, 1984). Therefore, if $\mathrm{T}$ pili were responsible for these changes, then a plasmid determining fewer of them (Rtsl) would have al lesser effect. Rts 1 was therefore tested in the recipients with each of the surface mating plasmids. Both plate/broth transfer frequency ratios were reduced by about 15 -fold only (Table 2 ). Another way of reducing the number and type of $\mathrm{T}$ pili synthesized by the recipient was to grow it at $37^{\circ} \mathrm{C}$ (see above). Therefore, the ability of R402 to improve the liquid mating characteristics of $\mathrm{Sa}$ at $37^{\circ} \mathrm{C}$ as opposed to $30^{\circ} \mathrm{C}$ was tested (Table 2). The plate/broth transfer frequency ratios were 27000 with no plasmid in the recipient, and about 1400 with R402 present, giving an improvement of 19fold. T pili were thus able to stabilize mating aggregates of the RP4 and $\mathrm{S}_{i}$ surface mating systems in a liquid to a degree depending on their numbers.

\section{DISCUSSION}

pIN25 was a typical IncT plasmid, but Rtsl was not. It was larger than the other three, it was repressed, not derepressed, for transfer at $30^{\circ} \mathrm{C}$, and it did not determine conjugative pili constitutively. 
The temperature-sensitivity of the Rts 1 transfer system was demonstrated using liquid mating by Terawaki et al. (1967). However, we found that the degree of temperature-sensitivity was about 1000 -fold less when surface mating was used. Rts1 transfer was only about 120 -fold lower at $37^{\circ} \mathrm{C}$ compared with transfer at $30^{\circ} \mathrm{C}$. Of the remaining three plasmids, R394 and pIN25 transferred almost as well on plates at $37^{\circ} \mathrm{C}$ as at $30^{\circ} \mathrm{C}$, but $\mathrm{R} 402$ transferred about 15 -fold less effectively at the higher temperature. The differences in transfer characteristics in liquid and on a surface were associated with changes in piliation. A mixture of long and short pili was found on cells carrying the derepressed plasmids at permissive temperatures. The long pili disappeared in cultures grown above $37^{\circ} \mathrm{C}$, but many short ones were present. It might be argued that the short pili were broken pieces of longer ones. This certainly seems quite likely at lower temperatures, but since there were virtually no long pili above $37^{\circ} \mathrm{C}$, the short ones could not be the result of fracturing. Their inability to mediate mating in a liquid was presumably because they were too small to function adequately in an environment where shear forces due to convectional and Brownian motion would be experienced. These forces would be much reduced on a plate, and, like the rigid pili described elsewhere (Bradley, 1980), the short stubs could mediate conjugation efficiently. Long $T$ pili were able to act as stabilizing pili in liquids like thin I pili (Bradley, 1984). They changed surface-mating rigid pilus systems to surface + liquid ones, and therefore combined the functions of thick and thin I pili (see Bradley, 1984). The fact that long and short $\mathrm{T}$ pili were presumably the same protein, and differed only in length, shows that the temperature-sensitivity of the conjugation systems of the plasmids was due to a control on the pilus length at elevated temperatures, perhaps because pilus protein (pilin) was not synthesized efficiently. In this event, the pool of unpolymerized pilin would be insufficient to allow pilus outgrowth to normal lengths from the numerous polymerization sites. These results therefore indicate that functions of the transfer operon other than those connected directly with pili are unaffected at elevated temperatures. In addition, it has been demonstrated that short pili, even though they may be flexible, are limited to functioning on a surface only, like rigid pili. Consequently, some pili characterized as rigid (Bradley, 1980) could in fact be short flexible ones. Since a morphological distinction is difficult to detect (Bradley, 1980), the pilus type should be termed 'surface mating' or simply 'short', unless the rigid character can be clearly demonstrated by visualizing broken pili.

An interesting point concerning phage $t$ is its adsorption to the short pili. Since it can adsorb but cannot proliferate at $37^{\circ} \mathrm{C}$, some point in the intracellular multiplication stage of the infective process must be temperature-sensitive. This character is analogous with that of phage pilH $\alpha$ (Coetzee et al., 1985) which is specific for both temperature-sensitive and temperaturetolerant $\mathrm{H}$ plasmids, though it multiplies only at about $30^{\circ} \mathrm{C}$.

We are grateful to Drs N. Datta and S. B. Levy for supplying the plasmids and to Dr D. E. Taylor for comments on the manuscript. The Medical Research Council of Canada provided financial support (grant no. MT5608).

\section{REFERENCES}

BRADLEY, D. E. (1967). Ultrastructure of bacteriophages and bacteriocins. Bacteriological Reriews 31, 230-314.

Bradley, D. E. (1980). Morphological and serological relationships of conjugative pili. Plasmid 4, 155169.

Bradley, D. E. (1984). Characteristics and function of thick and thin conjugative pili determined by transfer-derepressed plasmids of incompatibility groups $\mathrm{I}_{1}, \mathrm{I}_{2}, \mathrm{I}_{5}, \mathrm{~B}, \mathrm{~K}$ and $\mathrm{Z}$. Journal of General Microbiologl 130, 1489-1502.

Bradley, D. E. \& Fleming, J. (1983). Incompatibility group identification for repressed plasmids using host cell lysis by specific bacteriophages. Journal of Microbiological Methods 1, 171-176.

Bradley, D. E., Taylor, D. E. \& COhen, D. R.
(1980). Specification of surface mating systems among conjugative drug resistance plasmids in Escherichia coli K-12. Journal of Bacteriology 143, 1466-1470.

Bradley, D. E., Coetzee, J. N., Bothma, T. \& Hedges, R. W. (1981). Phage $t$ : a group T plasmiddependent bacteriophage. Journal of General Microbiology 126, 397-403.

Coetzee, J. N., Datta, N. \& Hedges, R. W. (1972). R factors from Proteus rettgeri. Journal of General Microbiology 72, 543-552.

Coetzee, J. N., Bradley, D. E., Fleming, J., du Toit, L., Hughes, V. M. \& Hedges, R. W. (1985). Phage pilH $\alpha$ : a phage which adsorbs to IncHI and IncHII plasmid-coded pili. Journal of General Microbiology 131, 1115-1121 
DATTA, N. (1977). C'assification of plasmids as an aid to understanding their epidemiology and evolution. Joumal of Antimicrobial Chemotherapy 3 (suppl. C), 1923.

IshiHARa, M., Kamio, Y. \& Terawaki, Y. (1978). Cupric ion resistance as a new genetic marker of a temperature-sensitive R plasmid Rtsl in Escherichia coli. Biochemical and Biophysical Research Communications 82, 74-80.

Jacob, A. E., Shapiro, J. A., Yamamoto, L., Smith, D. I.. Collen, S. N. \& Berg, D. (1977). Plasmids studied in Excherichia coli and other enteric bacteria. In DNA Insertion Elements, Plasmids and Episomes, pp. 607 638. Edited by A. I. Bukhari, J. A. Shapiro \& S. L. Adhya. New York: Cold Spring Harbor Laboratory.

KaDO, C. I. \& LIU, S. T. (1981). Rapid procedure for the detection and isolation of large and small plasmids. Joumal of Bacteriology 145, 1365-1373.

Levy, S. B., Hedges. R. W., Sullivan, F., Medeiros, A. A. \& Sosrosputro, H. (1985). Multiple antibiotic resistance plasmids in Enterobacteriaceae isolated from diarrhoeal specimens of hospitalized children in Indonesia. Journal of Antimicrobial Chemotherapy 16 (in the Press).
Matthew, M. \& Hedges, R. W. (1976). Analytical isoelectric focussing of $\mathrm{R}$-factor determined $\beta$ lactamases: correlation with plasmid compatibility. Journal of Bacteriologl 125, 713718.

OdakURa, Y., Hashimoto, $\mathrm{H}$. \& Mitsuhashi, $\mathrm{S}$. (1977). Temperature sensitive R plasmids isolated from Proteus strains. Microbiology and Immunology. 21, 621-629.

TAYLOR, D. E. (1983). Transfer-defective and tetracycline-sensitive mutants of the incompatibility group $\mathrm{H} 1$ plasmid $\mathrm{R} 27$ generated by insertion of transposon 7. Plasmid 9, 227-239.

TAYLOR, D. E. \& Levine, J. G. (1980). Studies of the temperature-sensitive transfer and maintenance of $\mathrm{H}$ incompatibility group plasmids. Journal of General Microbiology 116, 475-484.

TERAWAKI, Y. \& Rownd, R. (1972). Replication of the $\mathrm{R}$ factor Rtsl in Proteus mirabilis. Journal of Bucteriology 109, 492-498.

Terawakl, Y., Takayasu, H. \& Akiba, T. (1967). Thermosensitive replication of a kanamycin resistance factor. Journal of Bacteriology 94, 687-690.

Tetaz, T. J. \& Luke, R. K. (1983). Plasmid-controlledresistance to copper in Escherichia coli. Journal of Bacteriology 154, 1263-1268. 